\title{
Role of Institutional Credit on Agricultural Production: A Time Series Analysis of Pakistan
}

\author{
Maqbool Hussain Sial \\ Professor and Dean Faculty of Management \& Administrative Sciences, University of Sargodha, Pakistan \\ Masood Sarwar Awan \\ Assistant Professor Department of Economics, University of Sargodha, Pakistan \\ Muhammad Waqas \\ Graduate Student, Department of Economics, University of Sargodha, Pakistan
}

Received: July 20, 2010

Accepted: January 13, 2011

doi:10.5539/ijef.v3n2p126

\begin{abstract}
In our predominant and cash-strapped agrarian sector, adequate credit provision is a definite buttress to implant technological advancements, achieve technical efficiency and hire efficient inputs to uplift agriculture output/income collectively and eradicate poverty eventually. In the midst of beleaguered informal credit sector and recent spurt in banking services in last decade diverted the attention to envisage the formal sector's optimum potential. In this backdrop, this study is going to explore the role of institutional credit in agricultural production using the time series data for the period of 1972 to 2008. Cobb-Douglas production function is estimated using OLS and all the variables are transformed to per cultivated hectare. Results show that agricultural credit, availability of water, cropping intensity and agricultural labor force are positively significantly related to agricultural production.
\end{abstract}

Keywords: Agricultural Credit, Time series analysis, Pakistan

\section{Introduction}

Pakistan's agriculture sector is confronting many challenges like the shortage of energy and water along with rising prices of inputs like seeds, fertilizers, pesticides etc. Mostly small farmers are facing rigorous circumstances and seem to be unable to live with agriculture sector. They require credit for the purchase of seeds, fertilizers and other inputs. This credit is either comes from farmers saving or barrowings. The farmers of less developed countries like Pakistan have no chance to save the money. That's why farmers especially, small farmers borrow money from formal and informal lenders. Formal lenders like Zarai Taraqiati Bank Limited (ZTBL), Commercial Banks, Punjab Cooperative Bank provide loans on collateral but informal lenders like village shopkeepers; commission agents etc. demand no collateral.

Before 1972, Agricultural Development Bank (ADBP) was the most prominent agriculture lending institution in Pakistan. In 1972 commercial banks boosted their loan portfolio for agriculture purposes. State Bank of Pakistan (SBP) started crop loan insurance scheme assembles district wise agriculture credit data, started one-window operation to make agricultural credit access able and beneficial especially for small farmers. Agricultural loans was at its highest position during 2007-08, where rupees 211560 million were disbursed against rupees 168830 million to last year. During 2008-09 all the institutional lenders shrinked their loan portfolio for agriculture sector and total disbursement was rupees 151860 million.

Zuberi (1989) investigates that the impact of finance to seeds and fertilizers is significantly related with agricultural credit. Agriculture output also effected through institutional financing of capital investment (Qureshi and Shah, 1992). Relationship between institutional credit and agricultural Gross Domestic Product (GDP) was positively significant, explored by Iqbal and Munir (2003). Study also identified that irrigation water availability, cropping intensity and per cultivated hectares of agricultural labor were the other determinants of agricultural GDP. This study, by using time series data estimate the agricultural production function and try to dig out the impact of institutional credit and other variables like availability of water, labor force and cropping intensity on Agricultural GDP. The rest study is comprises on five parts. History of institutional credit in Pakistan is discussed in second part. Third and fourth part explains data \& methodology and results \& discussion, respectively. Last part concludes the study findings and then recommends some options to make agricultural credit scheme more efficient.

\section{History of institutional credit in Pakistan}

In 1958 West Pakistan Agriculturists Loan Act (ALA) regulated Taccavi loans which were the only source of agricultural loan since pre-independence. Provincial Government's Revenue Department disbursed Taccavi loans for the purpose of purchasing seeds, fertilizers and other implements (Yusuf, 1984 and Pakistan, 2003). Since 
1993-94 Taccavi loans are ceasing due to the efficient contribution of other credit institutions. Along with other Taccavi loans, cooperative societies and cooperative banks were another source of institutional credit, prior to independence (Iqbal et al., 2003). The aim of cooperative societies was to give finance to farmers for consumption expenditures and formulated to compete with non-institutional credit sources (Qureshi and Shah, 1992). Federal Bank for Cooperatives (FBC), with an aim to changed fundamental manners of credit, was established in 1976. State bank of Pakistan (SBP) give support to FBC (Iqbal et al., 2003).

In 1950's Agriculture Bank and Agricultural Development Finance Corporation were formed. In 1961, these were merged into Agricultural Development Bank, which is known as ZTBL. Agricultural credit estimates is prepared by Agricultural Credit Advisory Committee (ACAC) of SBP and National Credit Consultative Council (NCCC) approved annual credit plan. FBC disburse loans for production purposes while, ZTBL and commercial banks disburse loans for both consumption and production purposes. In 1972, commercial banks boosted their loan portfolio for agricultural purposes. Before this ADBP was the most prominent institute that distributed loans to farmers. Allied Bank limited (ABL), United Bank limited (UBL), National Bank limited (NBP), Muslim Commercial Bank (MCB) and Habib Bank Limited (HBL) received targets from State Bank of Pakistan in 1972, but failed to meet the objectives. Now SBP adopt certain things to make credit financing more beneficial. Crop loan insurance scheme was started by SBP, which helps to control loan losses that banks faces due to uncertainty in agriculture production. It assembles the district wise agricultural credit data, which helps the policy makers to put into practice such policy that is beneficial in reality. SBP advises banks to open $20 \%$ of their branches in rural areas. To remove the red-tapism in the path of loan distribution, SBP started one window operation. SBP is trying to increase the agricultural finance up to 3.3 million people. Due to the introduction of new 14 domestic banks for agricultural credit, the share of credit disbursement of private banks has increased. Total credit disbursement was at its highest position during 2007-08 that was 211,560.66 million rupees and distributed the lowest credit during 2000-01 that was 44,790.40 million rupees. ZTBL was at the top in the credit disbursement during 2008-09 distributed 45,399.87 million rupees, while domestic private banks and cooperatives distributed 18,557.24 and 3,538.89 million rupees, respectively. With the passage of time, share of ZTBL, domestic banks, cooperatives and commercial bank's share increases but in 2008-09 all banks shrinked their agricultural credit disbursement (Pakistan, 2008).

Percentage of loan advanced by institutions to subsistence holding was at its peak during 1987-88. These institutions disbursed $78 \%$ of loan to small farmers. This percentage was at its low level in 1992-93.

In 2004-05 this percentage was at 74\%. Economic land holders enjoyed the best percentage of agriculture credit during 1995-96 and 1996-97. In 2004-05 this was 18\%. Percentage share of agriculture credit for subsistence farmers tends to increase with the passage of time as compared to economic and above economic farm holders.

\section{Literature Review}

Nguyen (2007) tried to highlight the characteristics of rural credit market of Vietnam. By using the time series data for the period of 1993-1998 study also explored formal and informal credit characteristics and its impact on obtained credit amount. The study concluded that both household demand for credit and lenders supply of credit market. Fixed assets holding, education, health and distance from bank were the factors that affect credit activities of household. A participation probability of demand and supply of credit was found by using univariate and multi variate probit models.

Ibrahim et al. (2007) found that in Ethopia informal sector was the main source of credit in rural and urban areas. The study concluded that by reducing bureaucracy, transportation cost and other barriers in the way of credit disbursement will enhance the agricultural output.

Burgess and Pande (2005) tried to examine the impact of bank branch expansion on state output and poverty by using panel data for the period of 1961-2000 of India. Results showed that bank branch expansion increases non-agricultural output and it also increase share of rural credit and saving.

Guirkinger and Boucher (2005) found that informal credit and productive assets endowments were the factors that increases credit constrained household's productivity.

Nuryartono et al. (2005) found that under certain condition 18.1 percent of the household were addressed as no credit constraints household. 21.5 percent of households have access to formal credits in the rural areas of Central Sulawesi Province. Self selection problem and collateral constraints were the factors of credit constraints. The study tried to dig out the determinants of credit constrained household, focusing on the formal credit market by using a probit model. By applying switching regression model the study tried to highlight the affect of credit constrained household on the production of rice. Probit model results showed that human capital, wealth and risk-bearing indicators were significant in determining whether a household is credit constrained or not. Duca and Rosenthal 
(1993) argued that if a farmer's demand for credit exceeds than lenders supply of credit he will be credit constrained.

Stiglitz and Weiss (1981) found that amount of available credit is directly influenced by income or wealth level of borrowers, whereas wealth level has inverse relationship between costs of credit. The problem where the lender bears risk of the transaction and the borrower project benefits can be referred as an information problem among both Without partial or full collateral first-best allocation of credit is not possible. Thus scarce collateral implies that some individuals will be deprived of credit but those who have the collateral they obtain the credits. Similarly, Banerjee (2001) was of view that high-income individuals borrowed large amounts of credit at low costs but low-income borrowed a small amount of credit at high cost. The study suggested a direct relationship between amount and credit and level of income or wealth, whereas level of income or wealth was inversely related with amount of credit.

\section{Data and Methodology}

The study used the time series data collected from various publications of Government of Pakistan and from ZTBL and other credit institution records. The study used the data for the period of 1972 to 2008. Dependant variable is agricultural gross domestic product while, availability of water, agricultural credit, agricultural labor force and cropped area are independent variables. Independent variables are assumed as the factors of agricultural production. No doubt improved seeds and other inputs play main role in agricultural production and these can be directly influenced by the availability of agricultural credit. That's why variable of agricultural credit is used instead of all these factors. Agricultural credit does not affect the agricultural output directly but it affect indirectly. On technical grounds it is being criticized to use agricultural credit as independent variable. Agricultural credit is very important in agriculture production because availability of credit removes financial constraints relating to cash inputs, secondly technical efficiency of farmers will increase and thirdly agricultural credit will increase resource allocation and profitability.

Employing an endogenous switching regression model, Sial and Carter, 1996 estimated the effect of credit on small farms productivity on cross data of borrowers and non-barrowers in Punjab- Pakistan. Their results shows that individual would generate an extra output of worth rupees 3.05 with 1 rupee loan. In the dearth of targeted credit, small farmers' capital shadow price was 200 percent, which illustrates capital and other financial markets inefficiency. Targeted credit borrowers produced 93 percent more output and had 86 percent higher income as compared to non-borrowers.

Qureshi and Shah (1992) dropped the important variables like water and land in their analysis in order to remove multicollinearity. Iqbal et al. (2003) included both variables in their analysis and to control multicollinearity problem transformed all variables to pre cultivated hectare. By following same technique, the study transformed all dependant and independent variables to per cultivated hectare. Estimated equation of Cobb-Douglas production is as follow.

$$
L G D P C L T=\beta_{0}+\beta_{1} L I N C L T+\beta_{2} L A L C L T+\beta_{3} L A W C L T+\beta_{4} C R O P I N+\beta_{5} D U M M Y+U
$$

Where

LGDPCLT $=$ Natural logarithm of agricultural gross domestic product per cultivated hectare.

LINCLT $=$ Natural logarithm of agricultural credit per cultivated hectare.

LALCLT $=$ Natural logarithm of agricultural labor force per cultivated hectare.

LAWCLT $=$ Natural logarithm of farm gate availability of water per cultivated hectare. CROPIN $=$ Cropping intensity which was the ratio of total cropped area to cultivated area.

DUMMY $=$ for bad years $(1=$ for years 1974-75, 1983-84, $1992-93$ and 2000-01; otherwise 0 )

$\mathrm{U}=$ random error.

\section{Results and discussion}

Figure 3 shows the situation of institutional credit as percentage to agricultural gross domestic product (GDP) for the period of 1970-71 to 2007-08. Institutional credit as percentage to gross domestic product was at its highest point during 1986-87. After this period there is a decreasing trend in this percentage. This ratio is somewhat at a better condition during 2006-07 but again in 2007-08 institutional credit as percentage to gross domestic product declines.

Cobb-Douglas production function is estimated by using ordinary least square (OLS) method. Firstly original production function is estimated. Correlation matrix shows serious problem of multicollinearity. Bruesh-Godfrey serial correlation LM test investigate the presence of severe autocorrelation. Then all the variables are transformed into natural $\log$ of the variable per cultivated hectare. Again problem of autocorrelation is detected by God-Frey serial correlation LM test but the problem of multicollinearity is removed. Augmented Dickey-Fuller (ADF) and 
Phillips-Perron (PP) Unit root tests are used to check stationarity. The problem is found in many variables but is cured by taking first difference. Therefore the regression equation is re-estimated by adjusting for AR (1) and MA (1). The final model is free from multicollinearity, hetrokedastcity and autocorrelation.

Result shows that agricultural production is influence by all the explanatory variables in the model. $\mathrm{R}^{2}$ value shows that $96 \%$ of the total variations in the agricultural production are explained by independents variables. All the variables are significant and according to expectations.

Agricultural credit is positively related to agricultural production and explores the thing that one percent increase in institutional credit will increase agricultural production by sixteen percent. The coefficients of institutional credit, farm gate water availability and cropping intensity was higher than Iqbal et al. (2003). Dummy variable is significantly negatively related to agricultural production, which shows that uncertainties like droughts; floods etc will decrease agricultural output.

\section{Conclusions}

Institutional credit disbursement shows an increasing trend during some past years. In 2007-08 credit disbursement was at its peak. ZTBL and Commercial banks add up to major share in formal agricultural credit disbursement. From 2000-01 commercial banks heighten their loan portfolio for agriculture sector. Increase in development and production loan portfolio from the entire formal institutions give boost to agricultural output. Agricultural credit was positively significant to agricultural GDP while, availability of water, crop intensity, agricultural labor force per cultivated hectare were the factors that enhance agricultural GDP.

It is therefore recommended to enlarge the agricultural credit disbursement particularly to small farmers. To take into custody the uncertainty in agriculture sector, crop insurance scheme must be initiated. This may be helpful in getting required recovery rates of agricultural loans. Agricultural credit given to farmers on the basis of productivity will help in targeting the needy persons and this will also shrink the loan losses. Because when productivity of such a farmer increases, then by selling agricultural output he will be able to return the loan easily.

In the bad years, share of consumption loans should be increased. Besides, relaxation of collateral for small loans will be helpful for poor farmers. Above and other similar options for agricultural credit will be helpful in removing rural poverty.

\section{References}

Agricultural Development Bank of Pakistan. Agricultural Credit Indicators, Islamabad: Central Information Department, MIS Division.

Agricultural Statistics of Pakistan. (2004-05). Islamabad: Economic Wing, Ministry of Food, Agriculture and Livestock.

Banerjee, A. (2001). Contracting constraints, credit markets and economic development. Massachusetts Institute of Technology, Department of Economics. Working Paper Series, 02-17.

Carter, M.R. (1989). The Impact Of Credit on Peasant Productivity and Differentiation in Nicaragua. Journal of Development Economics 31, 13-36.

Duca, J. V. and Rosenthal, H. H. (1993). Borrowing constraints, household debt, and racial discrimination in loan markets, Journal of Financial Intermediation 3, 77-103.

Economic Survey of Pakistan 2003-04, 2008-09. Islamabad: Economic Advisor's Wing, Finance Division.

Emana, B., Gemtessa, K., Lemessa, D. \& Ayele, G. (2005). Informal finance in Ethiopia. Occasional Paper No. 13. Association of Ethiopian Microfinance Institutions, Addis Ababa, Ethiopia

Guirkinger, C. and Boucher, S. (2005). Credit constraints and productivity in Peruvian agriculture, Department of Agricultural and Resource Economics, University of California - Davis, Mimeo.

Handbook on Best Practices in Agri/Rural Finance (2009). Agricultural Credit Department. State Bank of Pakistan

Ibrahim G, Kedir A and Sebastián Torres. (2007). Household-level Credit Constraints in Urban Ethiopia: working paper No.07/03 Department of Economics, School of Oriental and African Studies, University of London, Nottingham Business School, Nottingham Trent University, UK.

Iqbal, Muhammad, Ahamad, Munir and Abbas, Kalbe. (2003). The Impact of Institutional Credit on Agricultural Production in Pakistan. The Pakistan Development Review 42(2), 469-485.

Nuryartono N, Zeller M. and Stefan Schwarze. (2005). Credit Rationing of Farm Households and Agricultural production: Empirical Evidence in the Rural Areas of Central Sulawesi, Indonesia. Conference on International Agricultural Research for Development Stuttgart-Hohenheim, October 11-13, 2005.

Qureshi, Sarfraz Khan and Akhtiar H. Shah. (1992). A Critical Review of Rural Credit Policy in Pakistan. The Pakistan Development Review 31(4), 781-801. 
Sial, M. H. and Carter, M. R. (1996). Financial Market Efficiency in an Agrarian Economy: Microeconometric Analysis of the Pakistani Punjab. The Journal of Development Studied 32(5), 771-798.

Stiglitz, J. E. and Weiss, A. (1981). Credit rationing in markets with imperfect information. American Economic Review 71(3), 393-410.

Yusuf, Muhammad. (1984). In Farm Credit Situation in Asia. Tokyo: Asian Productivity Organization. 455-494.

Zuberi, Habib A. (1989). Production Function, Institutional Credit and Agricultural Development in Pakistan. The Pakistan Development Review. 28(1), 43-56.

Table 1. Disbursement of agricultural credit by institutions from 1970-71 to 2007- 2008 (In million Rs)

\begin{tabular}{|c|c|c|c|c|c|}
\hline Years & ADBP & Commercial Banks & Taccavi Loans & Cooperatives & Total \\
\hline $1970-71$ & 92.7 & 80 & 10.2 & 38 & 220.9 \\
\hline $1971-72$ & 80 & 82 & 8.9 & 39.1 & 210 \\
\hline $1972-73$ & 168.8 & 85.7 & 10.2 & 42 & 306.7 \\
\hline 1973-74 & 415.2 & 286.4 & 67.5 & 144.2 & 913.3 \\
\hline 1974-75 & 395.5 & 520.9 & 12.3 & 81.5 & 1010.3 \\
\hline $1975-76$ & 532.2 & 808.1 & 25.7 & 91.8 & 1457.8 \\
\hline 1976-77 & 637.9 & 970 & 13.1 & 95.5 & 1716.5 \\
\hline $1977-78$ & 429.8 & 1290.9 & 9 & 318.4 & 2048.1 \\
\hline 1978-79 & 416.4 & 1381.2 & 12.8 & 486.4 & 2296.8 \\
\hline 1979-80 & 709.8 & 1587.4 & 9.2 & 677.1 & 2983.5 \\
\hline 1980-81 & 1066.2 & 1826.8 & 8.6 & 1026.8 & 3928.3 \\
\hline $1981-82$ & 1550.8 & 2436.4 & 8.5 & 1253.2 & 5248.9 \\
\hline $1982-83$ & 2297.7 & 2338.2 & 11.4 & 1312.3 & 5959.6 \\
\hline 1983-84 & 3097.6 & 3770 & 7.6 & 1212.8 & 8087.9 \\
\hline 1984-85 & 4101.3 & 4675.8 & 6.3 & 1660.1 & 10443.5 \\
\hline $1985-86$ & 5217.1 & 5321.9 & 4.6 & 1975.2 & 12518.8 \\
\hline 1986-87 & 5939.8 & 7305.6 & 13.3 & 2376.8 & 15635.5 \\
\hline $1987-88$ & 7598.5 & 5171.5 & 9.1 & 2864.4 & 15643.5 \\
\hline 1988-89 & 8526.8 & 3052 & 24.9 & 2559.7 & 14163.3 \\
\hline 1989-90 & 9271.4 & 3629.6 & 55.6 & 506.5 & 13463.1 \\
\hline 1990-91 & 8218.4 & 3861.8 & 56.3 & 2832 & 14968.5 \\
\hline 1991-92 & 6917.3 & 4172.2 & 56.3 & 2279.3 & 14125 \\
\hline $1992-93$ & 8533.5 & 4519.1 & 50.8 & 2721.8 & 15825.2 \\
\hline 1993-94 & 8877.9 & 4052.1 & 6.7 & 2432.5 & 15420.1 \\
\hline 1994-95 & 14399.6 & 4018.1 & 7 & 3553.3 & 21978.1 \\
\hline 1995-96 & 10260.5 & 5031.8 & 6.5 & 5923.2 & 21221.9 \\
\hline 1996-97 & 11563 & 4410.7 & 6.3 & 4919.8 & 20899.8 \\
\hline 1997-98 & 22128 & 5653.2 & 6.5 & 4722.9 & 32755 \\
\hline 1998-99 & 29886.5 & 7236 & 6.5 & 5440 & 42569 \\
\hline 1999-00 & 24171 & 9189 & 6.3 & 4301.6 & 37667.8 \\
\hline 2000-01 & 27293.2 & 11936.3 & 6.3 & 4829.5 & 44065.3 \\
\hline 2001-02 & 28848.4 & 17373.1 & 7.3 & 5126.2 & 51355.1 \\
\hline 2002-03 & 29107.6 & 22596.4 & 7.3 & 5594.7 & 57306 \\
\hline 2003-04 & 29693.5 & 33246.5 & & 7563.5 & 70503.5 \\
\hline $2004-05$ & 37216.9 & 51310 & & 7607.5 & 96134.4 \\
\hline 2005-06 & 47429.7 & 67929.8 & & 5889.5 & 121249 \\
\hline 2006-07 & 56232.2 & 80393.2 & & 5009.8 & 141635.3 \\
\hline 2007-08 & 45399.8 & 7436.6 & & 3538.8 & 151860.6 \\
\hline
\end{tabular}


Table 2. Results of Unit root tests.

\begin{tabular}{|c|c|c|c|c|c|c|c|c|}
\hline \multirow[b]{2}{*}{ Variables } & \multicolumn{4}{|l|}{$\mathrm{ADF}$} & \multicolumn{4}{|l|}{$\mathrm{PP}$} \\
\hline & Level & $\mathrm{P} *$ & Difference & $\mathrm{P}^{*}$ & Level & $\mathrm{Q}^{*}$ & Difference & $\mathrm{Q}^{*}$ \\
\hline \multicolumn{9}{|l|}{ With trend } \\
\hline LGDPCLT & -0.858 & 3 & $-4.515^{* * *}$ & 2 & -0.584 & 2 & $-5.147 * * *$ & 2 \\
\hline LINCLT & -1.342 & 1 & -2.784 & 1 & -2.304 & 1 & $-8.870 * * *$ & 5 \\
\hline LALCLT & -2.747 & 4 & $-4.522 * * *$ & 1 & $-3.218^{*}$ & 4 & $-7.297 * * *$ & 4 \\
\hline LAWCLT & -1.271 & 5 & $-3.659 * *$ & 2 & -1.561 & 6 & $-6.420 * * *$ & 6 \\
\hline CROPIN & -2.683 & 2 & $-4.230^{* * *}$ & 1 & -2.983 & 5 & $-7.198 * * *$ & 5 \\
\hline \multicolumn{9}{|c|}{ Without trend } \\
\hline LGDPCLT & 1.180 & 1 & $-4.594 * * *$ & 2 & 1.276 & 2 & $-4.216^{* * *}$ & 5 \\
\hline LINCLT & -1.627 & 2 & $-2.446^{* *}$ & 1 & -2.406 & 5 & $-8.713 * * *$ & 1 \\
\hline LALCLT & -1.910 & 1 & $-4.542 * * *$ & 1 & -2.655 & 6 & $-7.981 * * *$ & 2 \\
\hline LAWCLT & -1.912 & 3 & $-3.824 * * *$ & 2 & -2.515 & 4 & $-6.356^{* * *}$ & 4 \\
\hline CROPIN & -2.775 & 1 & $-4.949 * * *$ & 3 & -3.394 & 2 & $-7.209 * * *$ & 6 \\
\hline
\end{tabular}

Notes:.P* shows the maximum lag length, as determined by using AIC. Under PP test Q* shows Newey-West Bandwith, as determined by Bartlett-Kernel

*** shows $99 \%$ significance level; ** shows $95 \%$ significance level and * represents $90 \%$ significance level.

Table 3. Cobb-Douglas production estimation by using OLS

\begin{tabular}{|l|l|}
\hline Variables & Coefficients Estimates \\
\hline Constant & $5.944^{*}$ \\
\hline LINCLT & $0.167^{*}$ \\
\hline LALCLT & $0.639^{* *}$ \\
\hline LAWCLT & $1.063^{*}$ \\
\hline CROPIN & $1.399^{*}$ \\
\hline DUMMY & $-0.067^{*}$ \\
\hline AR $(1)$ & $0.255^{* *}$ \\
\hline MA(1) & $0.979^{* *}$ \\
\hline $\begin{array}{l}\mathrm{R}^{2}=0.96 \mathrm{~F}=160.1 \quad \text { Durbin-Watson Statistics }=1.96 \\
* *=99 \% \text { Significance level } \\
*=95 \% \text { Significance level }\end{array}$ \\
\hline
\end{tabular}

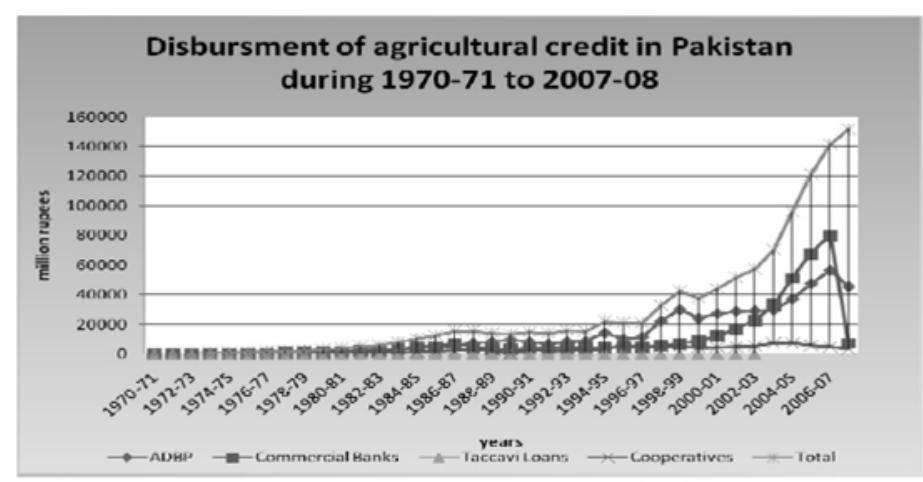

Source: Pakistan Economic Survey 2008-09

Figure 1. Disbursement of agricultural credit by institutions from 1970-71 to 2007- 2008 (In million Rs) 


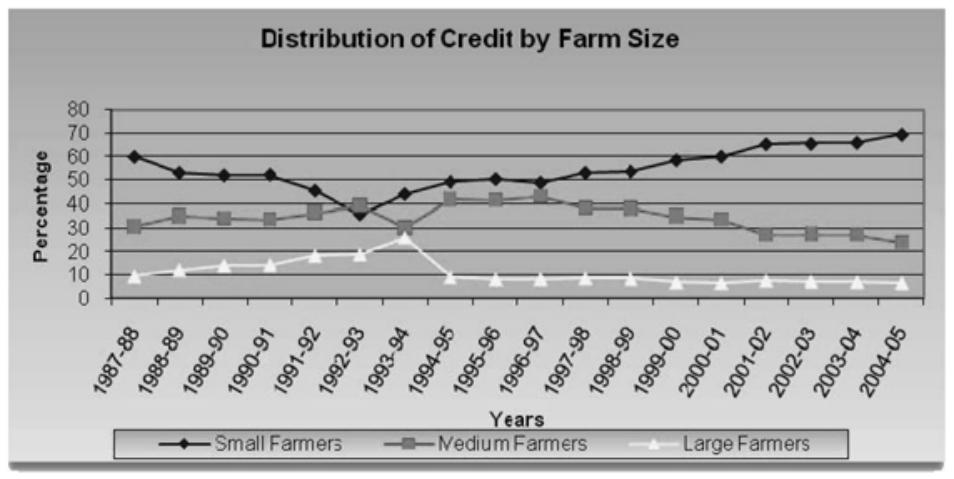

Source: Agriculture Statistics of Pakistan 2004-05

Figure 2. Agriculture credit advanced by commercial banks according to the size of holding 1987-2005

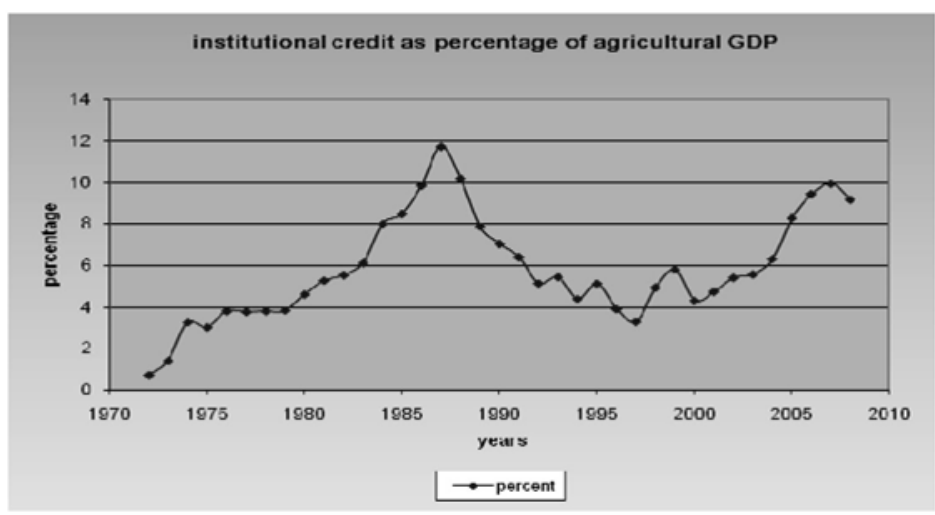

Sources:Economic Survey of Pakistan 2003-04, 2008-09.

Agricultural Development Bank of Pakistan

Agricultural Statistics of Pakistan 2004-05

Figure 3. Institutional credit as percentage to agricultural GDP 1970-2008 